\title{
Bio-Precipitation of Zn (II) from Municipal Wastewater Spiked with Zinc
}

\author{
Kamal Sherina ${ }^{1}$, Azhari Nik-Nuraini ${ }^{2}$ and Abdul-Talib Suhaimi ${ }^{3}$ \\ ${ }^{1,2,3}$ Institute for Infrastructure and Sustainable Mangament (IIESM), Faculty of Civil Engineering, \\ Universiti Teknolgoi MARA, Shah Alam, Selangor, Malaysia \\ ${ }^{2}$ Faculty of Engineering and Technology Infrastructure, Department of Civil Engineering, Infrastructure \\ University Kuala Lumpur (IUKL), Malaysia
}

Correspondence should be addressed to: Kamal Sherina; kamalsherina@hotmail.my

Received date: 4 March 2014; Accepted date: 25 March 2014; Published date: 15 July 2014

Academic Editor: Falah H Hussein

Copyright (C) 2014. Kamal Sherina, Azhari Nik-Nuraini and Abdul-Talib Suhaimi. Distributed under Creative Commons CC-BY 3.0

\begin{abstract}
This work was conducted to investigate the potential of using municipal wastewater as the source of sulphide and to evaluate the removal efficiency of zinc from municipal wastewater spiked with zinc. A two-stage experiment was carried out in a single $1 \mathrm{~L}$ anaerobic reactor operated for 13 days. In stage I, municipal wastewater containing sulphate was left under anaerobic condition for eight days for the production of biological sulphide. In stage II, the ability of biologically produced sulphide to precipitate out zinc from the wastewater spiked under three different concentrations of zinc $\left(10 \mathrm{mgL}^{-1}, 15 \mathrm{mgL}^{-1}\right.$ and $\left.20 \mathrm{mgL}^{-1}\right)$ was evaluated. The results showed that high percentage of sulphate reduction was achieved in non-sterilized samples (>90\%). A significant removal of zinc up to $56.87 \%$ was successfully removed from the non-sterilized samples spiked with $10 \mathrm{mgL}^{-1}$ of zinc.
\end{abstract}

Keywords: Anaerobic condition; biologically produced sulphide; sulphate reduction; zinc sulphide precipitation

\section{Introduction}

Zinc is an essential component which plays an important role in the human neuron system (Maret and Sandstead, 2006). However, the excess amount of zinc would lead to common cases of health effects including abdominal cramps, anaemia, nausea, diarrhea and vomits. In addition, zinc could also adversely affect the function of kidney, liver and lungs.

Thus, the removal of zinc is of vital importance to prevent further contamination of water bodies which will affect human health and environment. Zinc can be 
removed from waste stream by using chemical precipitation (Remoudaki et al., 2003; Reis et al., 2013). Zinc will react with precipitants such as carbonates, hydroxides or sulphides to form zinc precipitates (Kaksonen et al., 2003; Hoa et al., 2007; Sahinkaya et al., 2009).

Many researchers reported on the use of sulphate or sulphide of chemical origins as precipitants. If sulphate was used, additional carbon sources such as lactate, ethanol and acetic acid are required to assist the reduction of sulphate to sulphide (Huisman et al., 2006; Hoa et al., 2007; Bayradkar et al., 2009; Cibati et al., 2013). In addition, the inoculation of mixed culture of sulphate reducing bacteria by using anaerobic sludge from wastewater treatment plant or anaerobic digester effluent was needed to enhance the reduction process (Tuppurainen et al., 2002; Gonçalves et al., 2007; Sahinkaya et al., 2009).

The chemical precipitation using sulphide can be possibly applied to treat acid mine drainage and industrial wastewater containing heavy metals such as zinc.

In this study, the precipitant used was sulphide. The source of sulphide was from municipal wastewater. The sulphate originally present in municipal wastewater was reduced to sulphide. This process occurs naturally under anaerobic condition in the presence of organic materials and sulphate reducing bacteria. The main aim of this study was to biologically reduce sulphate to sulphide using municipal wastewater and to evaluate the performance of biologically assisted zinc sulphide precipitation.

\section{Materials and Method}

\section{Reactors set up}

Nine reactors with a working volume of $1 \mathrm{~L}$ were set up in this study as shown in Figure 1. A rubber stopper fitted with two tubes was used to seal the reactor. A stop valve was attached to each tube. The first tube was used to purge nitrogen gas into the reactor while the second tube was used to extract the wastewater sample from the reactor. This study was conducted under anaerobic condition. This was ensured by purging nitrogen gases for 10 minutes into each set of samples during the set up. Each reactor set up was equipped with magnetic bar and placed on the magnetic stirrer to ensure complete mixing. 


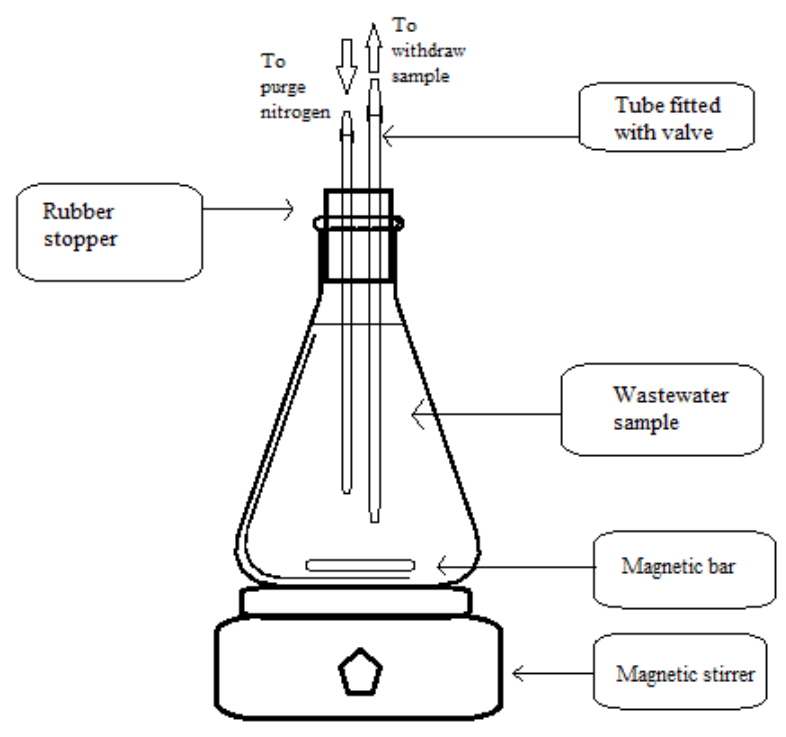

Figure 1: Reactor set up

\section{Sampling of municipal wastewater}

Raw municipal wastewater was collected from the inlet of wastewater treatment plant from Section 7, Shah Alam, Selangor, Malaysia. The wastewater treatment plant was designed to receive and treat 120000 PE. Wastewater was collected at $8.30 \mathrm{am}$ by using grab sampling method. The collected wastewater was stored in a $10 \mathrm{~L}$ high density polyethylene container which was tightly sealed and was taken to the environmental laboratory within 30 minutes.

\section{Experimental design}

Three different concentrations were investigated in this study; $10 \mathrm{mgL}^{-1}, 15 \mathrm{mgL}^{-1}$ and $20 \mathrm{mgL}^{-1}$. Three reactors were used for each zinc concentration; the first reactor was used as a control where the contents were sterilized using an autoclave at $121^{\circ} \mathrm{C}$ for 15 minutes. The remaining two reactors running in duplicates were used for biological sulphide production and zinc sulphide precipitation.
In the two stage experiment, reactors containing municipal wastewater were operated for 13 days. Stage I, running from day 1 to 8 investigated the production of biological sulphide while Stage II, running from day 8 to 13 focussed on metal sulphide precipitation.

\section{Experimental procedure}

Stage I: Study on Biological Sulphide Production (Sulphate Reduction to Sulphide) Performance on biological sulphate reduction was investigated during stage I, from day 1 to day 8. Samples were withdrawn using a $12 \mathrm{~mL}$ plastic syringe on day 1 and day 8 and placed in a $8 \mathrm{~mL}$ polyethylene sample tubes. Samples withdrawn were immediately stored under $4{ }^{\circ} \mathrm{C}$ which were later tested for sulphate, sulphite, thiosulphate, nitrate and phosphate.

Stage II: Study on Zinc-Sulphide Precipitation On day 8, all samples were spiked with zinc solutions to the pre-determined concentrations of $10 \mathrm{mgL}^{-1}, 15 \mathrm{mgL}^{-1}$ and 20 
$\mathrm{mgL}^{-1}$. A $200 \mathrm{mgL}^{-1}$ stock solution of zinc ions was prepared by dissolving $\mathrm{Zn}\left(\mathrm{NO}_{3}\right)_{2} \cdot 6 \mathrm{H}_{2} \mathrm{O}$ (F.S. Chemicals Malaysia) with ultra pure water $(18 \Omega)$ into a $1 \mathrm{~L}$ volumetric flask. Zincsulphide precipitation was investigated by withdrawing samples everyday from day 8 at the fixed time until day 13. Samples were withdrawn by using a $25 \mathrm{~mL}$ plastic syringe. Samples extracted were stored in a $60 \mathrm{~mL}$ of polyethylene sample bottles and preserved under $4^{\circ} \mathrm{C}$ which were later tested for zinc and nickel.

\section{Sample analysis}

Wastewater was characterized by analyzing the biological oxygen demand $\left(\mathrm{BOD}_{5}\right)$, chemical oxygen demand (COD), total suspended solids (TSS), volatile suspended solids (VSS), $\mathrm{pH}$ and temperature. $\mathrm{BOD}_{5}, \mathrm{COD}$, TSS and VSS were analyzed using Standard Method (APHA, 2012) while pH and temperature were measured using $\mathrm{pH}$ meter SensIon. The dissolved zinc concentrations were determined by using Perkin Elmer Optima 7300 DV Inductively coupled plasma optical emission spectroscopy (ICP-OES). Sulphate, sulphite, thiosulphate, nitrate and phosphate were measured using Metrohm 790 Ion Chromatography (IC).

\section{Statistical analysis}

Data on sterilized and non-sterilized samples for zinc-sulphide precipitation were statistically analyzed using T-test with a significance level of $\mathrm{P}<0.05$. All collected data were subjected to independent T-test.

\section{Results and discussion}

\section{Characterization of municipal wastewater}

The characteristics of municipal wastewater were evaluated by analyzing several parameters listed in Table 1.

Table 1: Characteristics of municipal wastewater

\begin{tabular}{|c|c|c|}
\hline Parameters & Unit & Value \\
\hline pH & - & 7.11 \\
\hline Temperature & $\stackrel{\mathrm{o}}{\mathrm{C}}$ & 25.12 \\
\hline Biological oxygen demand $\left(\mathrm{BOD}_{5}\right)$ & $\mathrm{mgL}^{-1}$ & 81.20 \\
\hline Chemical oxygen demand (COD) & $\mathrm{mgL}^{-1}$ & 213.33 \\
\hline Total suspended solids (TSS) & $\mathrm{mgL}^{-1}$ & 103.30 \\
\hline Volatile suspended solids (VSS) & $\mathrm{mgL}^{-1}$ & 206.67 \\
\hline Sulphate & $\mathrm{mgL}^{-1}$ & 14.25 \\
\hline Phosphate & $\mathrm{mgL}^{-1}$ & 7.63 \\
\hline Nitrate & $\mathrm{mgL}^{-1}$ & 0.55 \\
\hline Metals: & & \\
\hline Nickel & $\mathrm{mgL}^{-1}$ & ND \\
\hline Zinc & $\mathrm{mgL}^{-1}$ & 0.21 \\
\hline
\end{tabular}

Results from the characterization study showed that sulphate was present with an average concentration of $14.25 \mathrm{mgL}^{-1}$. The presence of sulphate indicated that the wastewater sample is suitable for this study as there was sufficient sulphate concentration for the production of biological sulphide. The determination of phosphate and nitrate were important because if these compounds are present in concentrations higher than the concentration of sulphate in samples, zinc sulphide may not form as reported by Bhagat et al., (2004) and Esposito et al., (2006).

Results on biological oxygen demand $\left(\mathrm{BOD}_{5}\right)$ which was $81.20 \mathrm{mgL}^{-1}$ indicated the presence of organic materials that are readily 
available to the microorganisms. Low concentration of zinc at $0.21 \mathrm{mgL}^{-1}$ and the absence of other metals will not cause significant interference with the study on zinc sulphide precipitation.

Stage I: Biological sulphate reduction
Sulphate concentrations were measured in all samples at day 1 and day 8 . Table 2 shows the averages of initial sulphate concentration in sterilized (control) and non sterilized samples to be $4.644 \mathrm{mg} \mathrm{SO}-\mathrm{SL}^{-1} 4.850 \mathrm{mg}$ SO4-SL ${ }^{-1}$ respectively.

Table 2: Sulphate and sulphide concentrations on selected days

\begin{tabular}{|l|c|c|l|c|}
\hline Conditions & $\begin{array}{l}\text { Initial sulphate } \\
\text { concentration } \\
\text { (mg S04-S L-1) }\end{array}$ & $\begin{array}{l}\text { Sulphate } \\
\text { concentration } \\
\text { on day 8 } \\
\text { (mg S04-SL }\end{array}$ & $\begin{array}{l}\text { Percentage } \\
\text { sulphate } \\
\text { reduction } \\
\text { (\%) }\end{array}$ & $\begin{array}{l}\text { Sulphide } \\
\text { concentration on } \\
\text { day 8 } \text { (mg SL-1) }^{-1}\end{array}$ \\
\hline Sterilized & 4.644 & 3.939 & 15.18 & 0.705 \\
\hline Non-sterilized & 4.850 & 0.053 & 98.91 & 4.797 \\
\hline
\end{tabular}

Sulphate concentration had decreased on day 8 in both sterilized and non-sterilized samples. Ideally sterilized samples act as control with no microorganisms present. In this study $15.18 \%$ of sulphate has been reduced in the sterilized samples. The percentage reduction was low compared to the non-sterilized samples. Microbes may have re-established during the 8 days of experiment. There was $98.91 \%$ reduction of sulphate in the non sterilized samples. A high reduction of sulphate in non-sterilized samples corresponded to higher generation rate of biological sulphides indicating higher activity of sulphate reducing bacteria in the present study.

The percentage reduction observed in this study was high compared to the study conducted by Tuppurainen et al., (2002) where the sulphate reduction was in the range of $30-40 \%$. Lower reduction of sulphate reported by Tuppurainen et al., (2002) was due to inhibition effects to biological activity by metals and low $\mathrm{pH}$. Sulphate and zinc were added simultaneously during the start up. Sulphate reducing bacteria present in reactor were not able to reduce sulphate to more than $40 \%$ with the presence of zinc.

The results of this study showed that nonsterilized samples have higher percentage removal of sulphate due to the presence of sulphate reducing bacteria. The high concentration of organic matter present has also led to rapid process of sulphate reduction by the sulphate reducing bacteria.

\section{Stage II: Zinc-sulphide precipitation}

Zinc removal through biologically assisted sulphide precipitation was investigated and the results are shown in Table 3. 
Table 3: Zinc removal through biologically assisted sulphide precipitation.

\begin{tabular}{|l|l|l|l|l|l|l|}
\hline \multicolumn{1}{|c|}{ Conditions } & \multicolumn{3}{c|}{ Sterilized } & \multicolumn{3}{c|}{ Non-sterilized } \\
\hline $\begin{array}{l}\text { Concentration of } \\
\text { zinc spiked at day 8 } \\
\left(\mathrm{mgL}^{-1}\right)\end{array}$ & 10 & 15 & 20 & 10 & 15 & 20 \\
\hline $\begin{array}{l}\text { Zinc removed on } \\
\text { day 13 (mgL-1) }\end{array}$ & 0.912 & 4.420 & 7.260 & $\begin{array}{l}5.367^{*} \\
(6.279)^{+}\end{array}$ & $\begin{array}{l}7.457^{*} \\
(11.87)^{+}\end{array}$ & $\begin{array}{l}8.482^{*} \\
(15.742)^{+}\end{array}$ \\
\hline $\begin{array}{l}\text { Biological sulphide } \\
\text { used to remove zinc } \\
\text { (mgL-1) }\end{array}$ & 0.497 & 2.409 & 3.958 & $\begin{array}{l}2.926^{*} \\
(3.424)^{+}\end{array}$ & $\begin{array}{l}4.066^{*} \\
(6.476)^{+}\end{array}$ & $\begin{array}{l}4.821^{*} \\
(8.583)^{+}\end{array}$ \\
\hline $\begin{array}{l}\text { Removal of Zinc on } \\
\text { day 13 (\%) }\end{array}$ & 9.19 & 28.70 & 35.12 & $\begin{array}{l}56.87^{*} \\
(66.06)^{+}\end{array}$ & $\begin{array}{l}55.12^{*} \\
(83.82)^{+}\end{array}$ & $\begin{array}{l}44.54^{*} \\
(79.66)^{+}\end{array}$ \\
\hline
\end{tabular}

* Nett removal, calculated by subtracting the removal in sterilized samples from the overall removal

+The observed overall removal rate.

The percentage removal for sterilized samples was in the range of $9.19-35.12 \%$. The lowest removal of zinc was $9.19 \%$ in the sterilized samples spiked with $10 \mathrm{mgL}^{-1}$ of zinc. In the sterilized samples of $15 \mathrm{mgL}^{-1}$ and $20 \mathrm{mgL}^{-1}, 28.70 \%$ and $35.12 \%$ of zinc were removed respectively. The removal of zinc may be attributed to the other mechanisms involved such as adsorption to the organic materials as reported by Tuppurainen et al., (2002) and Cohen et al., (2006).

The calculation for the percentage removal of zinc for non sterilized samples was calculated taking into account the results of the control experiments. The net percentage removal of non sterilized samples was calculated by deducting the removal observed in control experiments from the overall percentage removal. Net zinc removals in non-sterilized samples were found to be in the range of $44.54-56.87 \%$. The highest percentage removal of zinc $(56.87 \%)$ was achieved in the non sterilized samples spiked with $10 \mathrm{mgL}^{-1}$ of zinc. In the non sterilized samples spiked $15 \mathrm{mgL}^{-1}$, $55.12 \%$ of zinc was removed, while $44.54 \%$ of zinc was removed from the non sterilized sample spiked with $20 \mathrm{mgL}^{-1}$ zinc. The net zinc removal in non sterilized samples was attributed to the precipitation of insoluble zinc sulphide as a result of the biological sulphide produced by the biological activities of sulphate reducing bacteria.

Statistical analysis using T-test was conducted for means of sterilized and nonsterilized samples at different concencentrations of zinc; $10 \mathrm{mgL}^{-1}, 15 \mathrm{mgL}$ 1 and $20 \mathrm{mgL}^{-1}$. The T-test results showed that there was significant difference between the sterilized and non-sterilized samples for zinc-sulphide precipitation $(\mathrm{P}<0.05)$. The $\mathrm{T}$ test results prove that samples with or without sulphate reducing bacteria play a significant role in the biological sulphate reduction process. Hence, affecting the overall zinc removal in the zinc-sulphide precipitation process.

\section{Relationship of pH and zinc sulphide precipitation process}

Table 4 shows the relationship between $\mathrm{pH}$ and zinc sulphide during the precipitation process. 
Table 4: Relationship of $\mathrm{pH}$ and zinc sulphide precipitation process.

\begin{tabular}{|l|l|l|l|l|}
\hline $\begin{array}{l}\text { Concentrations of } \\
\text { zinc spiked on day } \\
\mathbf{8}\left(\mathbf{m g L}^{-1}\right)\end{array}$ & $\begin{array}{l}\text { pH on day 8 } \\
\text { before } \\
\text { addition of zinc } \\
\text { solutions }\end{array}$ & $\begin{array}{l}\text { pH on day 8 } \\
\text { after addition of } \\
\text { zinc solutions }\end{array}$ & Final pH \\
\hline Sterilized & \begin{tabular}{l} 
pH \\
\hline 10
\end{tabular} & 7.11 & 6.71 & 6.72 \\
15 & 7.72 & 7.12 & 6.87 \\
20 & 8.82 & 7.22 & 6.92 \\
\hline Non sterilized & 7.42 & 6.77 & 6.91 \\
\hline 10 & 7.40 & 7.14 & 6.99 & 7.10 \\
15 & 7.48 & 7.17 & 6.84 & 6.92 \\
\hline
\end{tabular}

Initial $\mathrm{pH}$ for sterilized samples was in the range of 8.70-8.82 while for non sterilized samples the ranged was between 7.40-7.63. The $\mathrm{pH}$ values dropped in both sterilized and non sterilized samples on day 8 before the addition of metals. $\mathrm{pH}$ value spiked with 10 $\mathrm{mgL}^{-1}$ for sterilized and non sterilized samples dropped from 8.76 to 7.11 and from 7.40 to 7.14 , respectively .The $\mathrm{pH}$ value dropped on day 8 was due to the utilization of organic materials during the sulphate reduction process. This condition was also supported by Sahinkaya et al., 2009. Chemical equation for sulphate reduction process is expressed as in equation (i) below:

$\mathrm{SO}_{4}{ }^{2-}+$ organic matter + anaerobic bacteria $\rightarrow \mathrm{S}^{2-}+\mathrm{H}_{2} \mathrm{O}+\mathrm{CO}_{2}$

After the addition of zinc solutions, $\mathrm{pH}$ value dropped for both samples. In sterilized samples spiked with $15 \mathrm{mgL}^{-1}$ of zinc, $\mathrm{pH}$ decreased from 7.72 to 7.12. Similarly, in non sterilized samples spiked with $15 \mathrm{mgL}^{-1}$ of zinc, $\mathrm{pH}$ value dropped from 7.17 to 6.99 . Similar findings were also reported by Sahinkaya et al., (2009) where $\mathrm{pH}$ in the reactor decreased to lower values at the higher initial of metals concentration. A drop of $\mathrm{pH}$ was due to the production of acid as expressed in equation (ii).

$\mathrm{Zn}^{2+}+\mathrm{HS}^{-} \rightarrow \mathrm{ZnS}+\mathrm{H}^{+}$

Towards the end of the study, pH increased in all non sterilized samples. The increase in $\mathrm{pH}$ proved that the precipitation process has occurred in non sterilized samples. This is consistent with the report published by Remoudaki et al., (2003), which stated that an increase in the $\mathrm{pH}$ of samples favour for metal precipitation.

\section{Conclusion}

In conclusion, sulphate was biologically reduced to sulphide in non sterilized municipal wastewater samples where almost 98.91\% sulphate reduction was achieved. Zinc precipitation with biological sulphide was possible with the highest zinc removal achieved was $56.87 \%$ in samples spiked with $10 \mathrm{mgL}^{-1}$.

\section{Acknowledgment}

This study was partially funded by World Federation of Scientist (WFS) and the Excellence Fund from Universiti Teknologi MARA, Shah Alam, Selangor, Malaysia.

\section{References}

1. APHA Standard, Methods for the Examination of Water and Wastewater, 22nd ed. (2012). American Public Health Association, Washington, DC, USA.

2. Bhagat, M., Burgess, J.E., Antunes, A.P.M., Whiteley, C.G. and Duncan, J.R. (2004). "Precipitation of mixed metal residues from 
wastewater utilising biogenic sulphide" Minerals Engineering, 17,952-932.

3. Bayradkar, A., Sahinkaya, E., Gungor, M., Uyanik, S. and Atasoy A. D. (2009). "Performance of sulfidogenic anaerobic baffled reactor (ABR) treating acidic zinccontaining wastewater" Bioresource Technology,10,4354-4360.

4. Cibati, A., Cheng, K.Y. Morris, C., Ginige, M.P., Sahinkaya, E., Pagnanelli, F. and Kaksonen, A.H "Selective precipitation of metals from synthetic spent refinery catalyst leach liquor with biogenic $\mathrm{H} 2 \mathrm{~S}$ produced in a lactate-fed anaerobic baffled reacto" Hydrometallurgy, 139, 154-161.

5. Cohen, R.R.H. (2006) "Use of microbes for cost reduction of metal removal from metals and mining industry waste streams" Journal of Cleaner Production, 14,1146-1157.

6. Esposito, G., Veeken, A., Weijima, J. and Lens, P.N.L. (2006) "Use of biogenicsulphide for ZnS precipitation" Separation and Purification Technology,51,31-39.

7. Goncalves, M.M.M., da Costa, A.C.A, Leite, S.G.F. and Sant'Anna Jr., G.L. (2007) "Heavy metal removal from synthetic wastewaters in anaerobic bioreactor using stillage from ethanol distilleries as a carbon source" Chemosphere,69,1815-1820.

8. Hoa, T.T.H., Liamleam, W. and Annachhatre, A.P. (2007) "Lead removal

through biological sulphate reduction process" Bioresource Technology,98,25382548.
9. Huisman, L., Schouten, G., and Schultz, C. (2006) "Biologically produced sulphide for purification of process streams, treatment and recovery of metals in metal and mining industry" Hydrometallurgy, 83,106-113.

10. Kaksonen, A.H., Franzman P.D. and Puhakka J.A. (2003) "Performance and ethanol oxidation kinetics of a sulphatereducing fluidized bed reactor treating acidic metal-containing wastewater" Biodegradation,14,207-217.

11. Remoudaki, E., Hatzikioseyian, A., Kousi, P. (2003) "The mechanism of metals precipitation by biologically generated alkalinity in biofilm reactors" Water Research,37,3843-3854.

12. Ries, F.D., Silva, A.M., Cunha E.C. and V.A. (2013) "Application of sodium- and biogenic sulfide to the precipitation of nickel in a continuous reactor" Separation and Purification Technology 120,346-353.

13. Sahinkaya, E., Gungor, M., Bayrakdar, A, Yucesoy, Z. and Uyanik, S. (2009) "Separate recovery of copper and zinc from acid mine drainage using biogenic sulfide" Journal of Hazardous Materials, 171,901-906.

14. Tuppurainen, K.O., Väisänen, A.O., and Rintala, J.A. (2002) "Zinc removal in anaerobic sulphate-reducing liquid substrate process" Minerals Engineering,15,847-852.

15. W. Maret, H.H. Sandstead,(2006) "Zinc requirements and the risks and benefits of zinc supplementation" Journal of Trace Elements in Medicine and Biology, 20,3-18. 